\title{
The 'Sekolah Sak Ngajine' Program; The Habit of loving the Qur'an from an Early Age based on Tilawati
}

\author{
Mustajab $^{1}$, Fathor Rozi ${ }^{2}$, Hasan Baharun ${ }^{{ }^{\bowtie}}{ }^{\text {, Hikmatul Maulidiya }}{ }^{4}$ \\ Pendidikan Agama Islam, Universitas Islam Negeri Kiai Haji Achmad Siddiq Jember, \\ Indonesia(1), Manajemen Pendidikan Islam, Universitas Nurul Jadid, Paiton, Probolinggo, \\ Indonesia(2), Pendidikan Agama Islam, Universitas Nurul Jadid, Paiton, Probolinggo, \\ Indonesia(3), Pendidikan Anak Usia Dini, Universitas Nurul Jadid, Paiton, Probolinggo, \\ Indonesia ${ }^{(4)}$
}

DOI: $10.31004 /$ obsesi.v6i3.1636

\begin{abstract}
This study aims to describe the implementation or application of the 'Sekolah Sak Ngajine' Program as a habit of loving the Qur'an from an early age in RA Khodijah II Sebaung, Gending District. The 'Sekolah Sak Ngajine' program is taken from the Javanese language, which means School While Reciting the Qur'an. This habituation program is packaged in Qur'an learning activities using the Tilawati method. This research uses a qualitative descriptive approach with the type of case study. This study found that the 'Sekolah Sak Ngajine' program can condition the tendency of the world of children to be active and challenging to concentrate so that the quality and quantity targets can be achieved well in learning the Qur'an. Through the 'Sekolah Sak Ngajine' program, it can have a tremendous impact on students, namely instilling the habit of learning the Qur'an to students so that they can foster a sense of love for the Qur'an from an early age in RA Khodijah II Sebaung, Gending District, Probolinggo Regency. The implication is that learning the Qur'an in early childhood requires creativity, patience, and patience from teachers in teaching.

Keyword : the 'sak ngajine school' program; habituation to love the Qur'an; tilawati method
\end{abstract}

\begin{abstract}
Abstrak
Penelitian ini bertujuan untuk menguraikan implementasi atau penerapan Program 'Sekolah Sak Ngajine' sebagai pembiasaan mencintai Al Qur'an sejak usia dini di RA Khodijah II Sebaung Kecamatan Gending. Program 'Sekolah Sak Ngajne' diambil dari Bahasa Jawa yang berarti Sekolah Sembari Mengaji Al Qur'an. Program pembiasaan ini dikemas dalam kegiatan pembelajaran Al Qur'an menggunakan metode Tilawati. Adapun penelitian ini menggunakan pendekatan deskriptif kualitatif dengan jenis studi kasus. Dari penelitian ini, diperoleh temuan penelitian bahwa program 'Sekolah Sak Ngajine' dapat mengkondisikan kecenderungan dunia anak yang aktif dan sulit konsentrasi sehingga target kualitas dan kuantitas dapat tercapai dengan baik dalam pembelajaran Al Qur'an. Melalui program 'Sekolah Sak Ngajine' dapat memberikan dampak yang sangat baik terhadap peserta didik yaitu Menanamkan pembiasaan belajar Al Qur'an terhadap peserta didik sehingga mampu menumbuhkan rasa mencintai Al Qur'an sejak usia dini di RA Khodijah II Sebaung Kecamatan Gending Kabupaten Probolinggo. Implikasinya, pembelajaran Al Quran kepada anak usia dini memerlukan kreativitas, kesabaran, dan ketelatenan guru dalam mengajar.
\end{abstract}

Kata Kunci: program 'sekolah sak ngajine'; pembiasaan mencintai al qur'an; metode tilawati

Copyright (c) 2021 Mustajab, et al.

$\triangle$ Corresponding author :

Email Address : ha54nbaharun@gmail.com (Paiton, Probolinggo, JawaTimur, Indonesia)

Received 2 June 2021, Accepted 23 Otober 2021, Published 27 October 2021 


\section{INTRODUCTION}

In Islam, children are God's mandate for parents, society, and the nation (Purba \& Maturidi, 2019; Trihapsari \& Mujahidah, 2021). The nation's children today determine the fate and future of the country in the future. Therefore, our joint task is to prepare the next generation of quality people, namely an age with solid faith, knowledge, good deeds, and noble character (Eka, 2017; Pusvitasari, 2021).

To create a qualified next generation of nations, one of the things that must be done is to form good behavior. Human behavior is determined by the environment, meaning that someone who grows up in an atmosphere of character will become a person of character (Rosada \& Sasmanda, 2018). Children are like sheets of white paper, which is first engraved in the soul and then forms the surface (Mansur, 2017). Thus, as the second environment where children learn, the school also has a systematic impact on the formation of children's awareness (Taja, Inten, \& Hakim, 2019).

Through the process of learning the Qur'an at school certainly makes students who are knowledgeable continuously increase rapidly (Robi, Sugiatno, Muhammad Taqqiyudin, Amimah Qodari, 2020). Habits include behaviors acquired through lifelong learning and eventually become consistent and spontaneous (Saugi, 2020). Thanks to the practice of loving the Qur'an from an early age, children will be able to get used to reading and memorizing. Then, the child will learn to understand it and apply it in everyday life (Rosada \& Sasmanda, 2018).

The primar effort to print a generation of Muslims who are insightful of the Qur'an is by teaching children to learn the Qur'an and trying to instill a high sense of love for the Qur'an to them (Ali \& Hussien, 2017; Ali \& Hussien, 2018; Wahyudin et al., 2021). This printing is intended to create a generation that will pursue certain businesses such as teaching, leading, leading, building humans with the spirit of the Qur'an (H, 2018; R. Ali \& Harahap, 2021).

Reading the Qur'an is not just about reading because the Qur'an contains principles that must be considered and understood (Santosa et al., 2016). Because if someone reads with the wrong rules, it also causes a misinterpretation of the Qur'an. Therefore, studying the Qur'an is very important so that Muslims can read the Qur'an with excellent and correct principles. The rules that must be followed when reading the Qur'an include alwakfu wal ibtida (the procedure for stopping and starting reading), the letter muroatul wal harokat wal ayat (pronunciation of letters, harokat and perfect verses), the letter mahorijul (where the notes come out), properties of khuruf (character letters), ahkamul khuruf (laws of khuruf), ahkamul mad wal koshor (long and short rights) and gorib Muskilat (foreign and difficult reading) (Syaikhon, 2017).

It takes a method in the teaching process of reading the Qur'an. This is because the method plays a vital role in achieving learning objectives. By using this method, one can develop a worldview, mental and personal. To enable students to receive lessons quickly, effectively, and practice well (Amin \& Ramli, 2019).

To achieve this goal, in 2018, the Chairman of the Tarbiyatussibyan Foundation, M. Mahin, attempted to create a flagship madrasa program, namely the 'Sekolah Sak Ngajine' Program. The 'Sekolah Sak Ngajine' program is taken from the Javanese language, which means School While Reciting the Qur'an. This program is packaged in Qur'an learning activities using the Tilawati method. The program is one of the attractions for parents who want their children to acquire knowledge and religious knowledge simultaneously. Thus, parents should not hesitate to send their children to study at RA Khodijah II Sebaung, Gending District, one of the educational institutions under the auspices of Tarbiyatussibyan. Through this program, children will be accustomed to learning and understanding the Qur'an so that a sense of love for the Qur'an can be embedded from an early age.

In explaining the topic of this research, the researcher seeks to review previous studies to obtain an in-depth analysis related to the habit of loving the Qur'an from an early age. In the first study that the author reviewed, it was stated that the progress of reading the Qur'an 
in children could increase when schools implemented the habit of reading Iqra 'every morning. In addition, such habituation can improve children's enthusiasm and motivation to read the Qur'an (Akbar, 2017). Then in the second study (Julianto, 2020), The results show that to grow the spirit of loving the Koran in children, it can be done by applying the ACQ (I Love Qur'an) gesture method that combines audio, visual, and kinesthetic learning models. Meanwhile, in the third study (Mulyani, Pamungkas, \& Inten, 2018), Efforts are made to create a sense of pleasure in children towards the Qur'an by applying storytelling techniques. This storytelling technique is done by telling stories contained in the Qur'an so that children are interested in reading verses related to the story.

The difference between this study and some relevant previous studies lies in the technical program initiated. The 'Sekolah Sak Ngajine' program aims to familiarize children with the love of the Qur'an from an early age through an organized and structured learning process. Of the various PAUD educational institutions in the Gending sub-district, RA Khodijah II is the only RA that initiated the 'Sekolah Sak Ngajine' program. This program based on the tilawati method was created considering the previous learning of the Qur'an was not optimal due to the lack of enthusiasm of the students. In general, such habituation programs are primarily developed in Al-Quran Education places that focus on studying the Qur'an. This is the point of uniqueness and novelty of this research.

Starting from the various explanations above, the researchers tried to integrate the concept of the tilawati method and the habit of reading the Qur'an in children. Growing children's love for the Qur'an must be done from an early age but with a fun method and a supportive environment so that a generation of Qur'ans who love and understand the contents of the Qur'an are printed (Ummah \& Wafi, 2017). Thus, the importance of learning the Qur'an through the implementation of the 'Sekolah SakNgajine' program as a habit of loving the Qur'an from an early age in RA Khodijah II Sebaung, Gending District, is the focus of this research.

\section{METHODOLOGY}

This study used a qualitative descriptive approach to obtain information and data related to the 'Sekolah Sak Ngajine' Program towards the habit of loving the Quran from an early age. This research applies a case study type in line with the research object that focuses on the 'Sekolah Sak Ngajine' Program. Through this type of research, the researcher seeks to uncover the characteristics and uniqueness of the case's object of research, namely the 'Sekolah Sak Ngajine' program.

The research site is located in Raudhatul Athfal Khodijah II Sebaung, Gending District, Probolinggo Regency. By applying a qualitative descriptive approach to the type of case study, the researchers tried to describe and analyze the application of the 'Sekolah Sak Ngajine' program as a habit of loving the Qur'an from an early age in Raudhatul Athfal Khodijah II. Technically, the flow of this research is as follows :

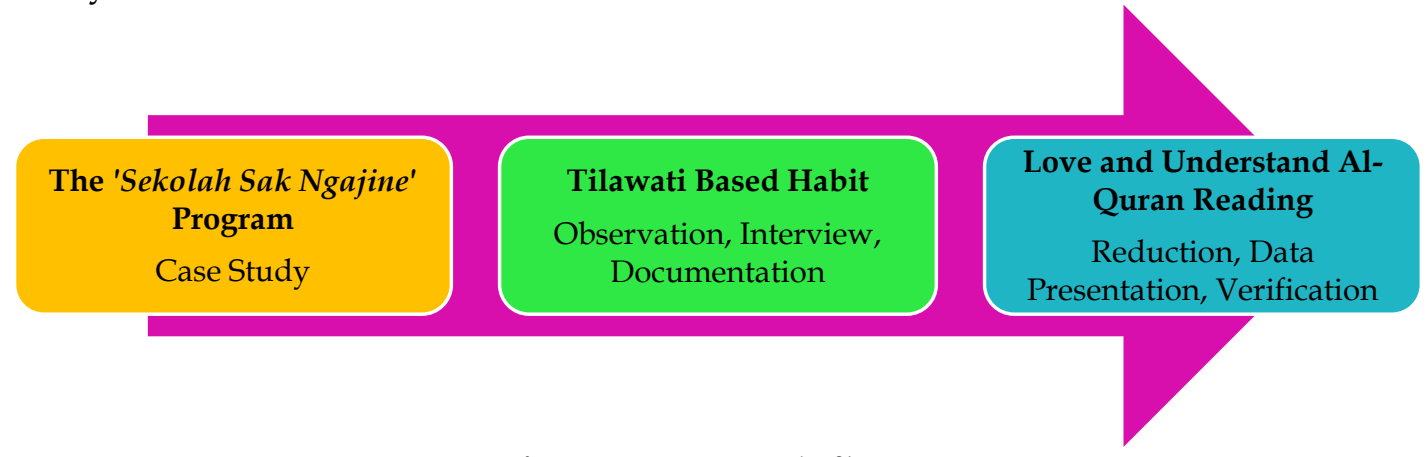

Figure 1. Research flow 
It can be seen from the graph on figure 1 that the researcher made direct observations to obtain the data needed for this research by field observations, in-depth interviews, and documentation to support the completeness of the data. In this case, the researcher goes directly to the field and interacts actively with the research item. The head of RA and the teacher council at RA Khodijah II became the primary informants in this study. Meanwhile, data analysis went through three steps: data processing or data selection, data presentation, validation, or concluding.

\section{RESULTS AND DISCUSSION}

The results of the research on the 'Sekolah Sak Ngajine' program as an effort to get used to loving the Koran from an early age based on tilawati applied at RA Khodijah II can be seen as follows;

\section{Tilawati-Based 'Sekolah Sak Ngajine' Program at RA Khodijah II}

By local wisdom and madrasa conditions, the priority of RA Khodijah II's flagship program is to improve quality and global competitiveness through character, religion, and competency development is the implementation of religious madrasas through the 'Sekolah Sak Ngajine' program. Head of RA Khodijah II (Ustidz, 2021) said that 'Sekolah Sak Ngajine' is a Quran learning program using the tilawati method to get used to loving the Koran from an early age. This program is carried out four days a week, effective learning days at school, namely Tuesday, Wednesday, Thursday, and Saturday, and is carried out after the end of the lesson.

In practice, this method of learning the Qur'an uses a classical and individual learning process. This combination of classical and individual learning is applied to variations in methods that prevent children from being bored. Thus, it can be by the tendency of the world of children who are active and challenging to concentrate so that the quality and quantity targets can be adequately achieved in learning the Qur'an. The following is a picture of implementing the 'Sekolah Sak Ngajine' program in general.

First, the teacher begins the lesson by praying with the students. This stage is carried out to prepare students' minds and psychologically in receiving the material to be studied. In addition, joint prayer aims to familiarize students to always ask for God's help in doing something. Before the prayer begins, the teacher will control the position of the students by asking them to sit in a $U$ shape. In a sitting place like this, the teacher is in the middle so that he becomes the center of students' attention. These steps can be seen in figure 2 .

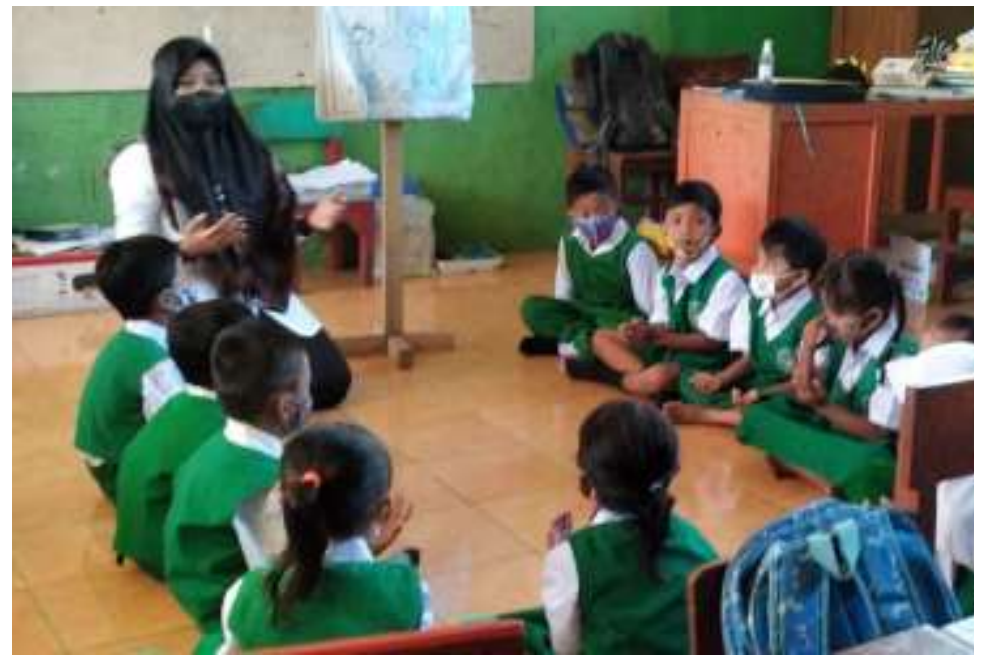

Figure 2. Opening prayer

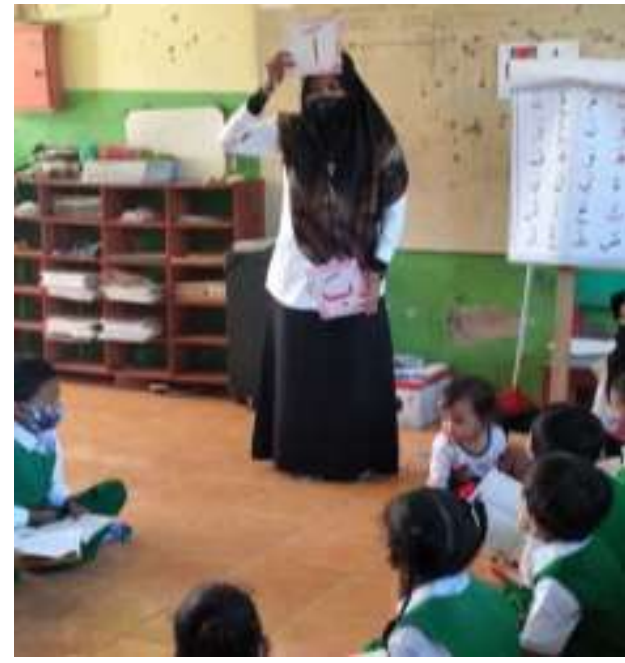

Figure 3. Classic card demonstration 
Second, do a card show. After starting the learning with a prayer together, the classical education was displayed using a card display. The time required in this classical approach is 5 minutes each. The classical learning process using the card display is done by the teacher introducing the subject of the hijaiyah letter by giving examples of the hijaiyah letter and asking the students the hijaiyah letter that has been explained. Then the teacher instills the concept of position direction (right-left, up-down, front-back) and the idea of numbers $(1,2$, and so on). The idea of planting the right and left positions used is the student's position. This classic card show/demonstration can be seen on figure 3 .

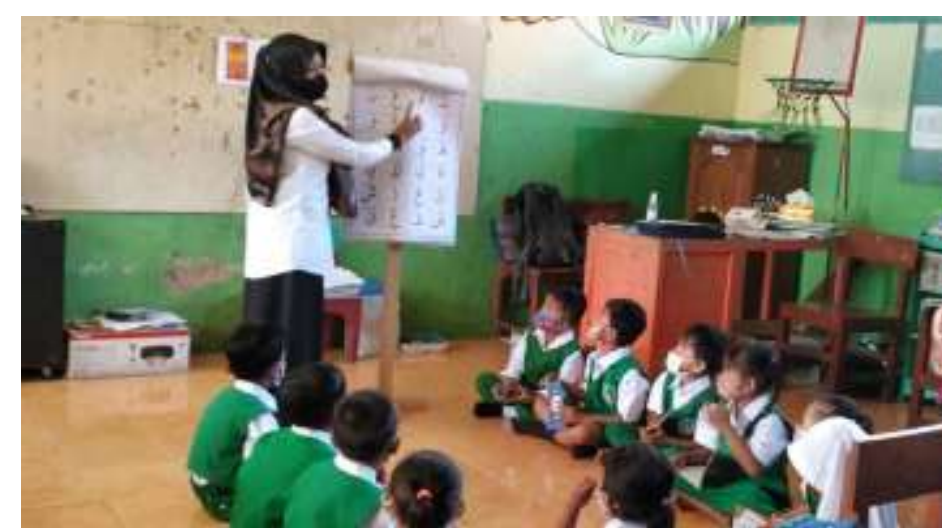

Figure 4. Classical calendar demonstration

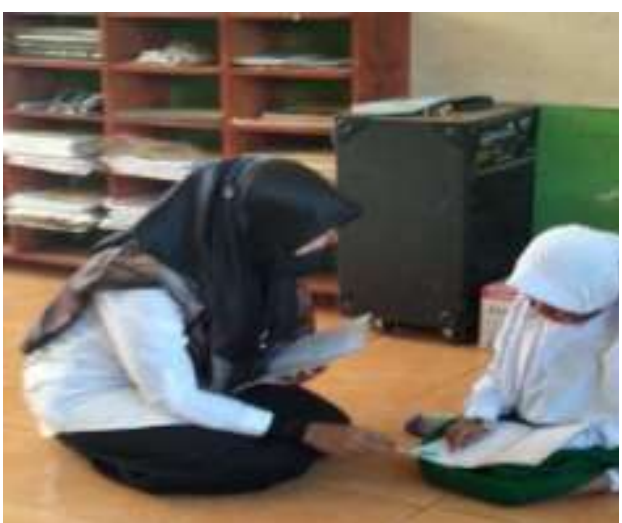

Figure 5. Individual book technique

Third, do a calendar display. The following classical learning after students recognizes hijaiyah letters is with a calendar display. This calendar display aims to train reading fluency (habituation), help students launch book reading and establish the reading of the initial pages when students reach the final page. Classical learning using a calendar display is divided into three stages. The first stage, the first meeting until the 20th, introduces one letter utilizing the song "this is the sound....." with four tones: flat-up-down-down. The second stage is the 21st to the 30th meeting, practice two-letter pronunciation by using the song "this sounds ..." with four styles: flat-up-down-down. The third stage is the 31st to 40th meetings, practice two-letter pronunciation using the Rost song with three tones: flat-up-down. This classical calendar display can be seen on figure 4 .

Fourth, individual learning using books takes 20 minutes. Unlike the previous stages, learning using this book is carried out with an individual approach. One of the teachers at RA Khodijah II (Maulidiyah, 2021) states that this stage is needed as a form of opportunity for students to implement the material at the previous step in reading the Qur'an. In this individual learning, students are divided into several groups. Some groups read the Qur'an, and other groups are given the task of coloring hijaiyah letters, writing Arabic, and others. Then the teacher comes or calls the students one by one and teaches the Qur'an by reading one page of the book that was conducted at that time using singing. After teaching the Qur'an, the teacher will ask questions by singing and pointing the letters, and students must answer the questions. Furthermore, the teacher provides an award for students' ability by placing an asterisk on the page. This individual learning can be seen on figure 5 .

Fifth, repeat calendar display. This repetition is done to strengthen students' memory and understanding of the material they have just learned. This repetition is also done so that students no longer make mistakes when asked to read the Qur'an individually.

Classical learning in the second to fourth stages, namely by displaying cards, calendars, and books, is applied to attract students' attention. Learning media such as cards and colorful calendars can generate interest so that students' focus will be on the press and teacher explanations. Jannah (2021) added that the song used to introduce letters can also create a sense of pleasure and prevent students from feeling bored when listening to the teacher's 
explanation. Not only that, the Rost rhythm or song used in reading the verses of the Koran will make students interested in reading the Koran. From the interest that is used as a habituation program, it can create a sense of love for the Qur'an.

Sixth, after all learning is done, the teacher closes and ends the lesson by reading a prayer which is seen on figure 6 . The reading of prayer in the end of the lesson also done classically to maintain the sudent's cohesiveness and enthusiasm. Of course, praying together at the end of the lesson also teaches students always to be grateful to Allah for the additional knowledge gained.

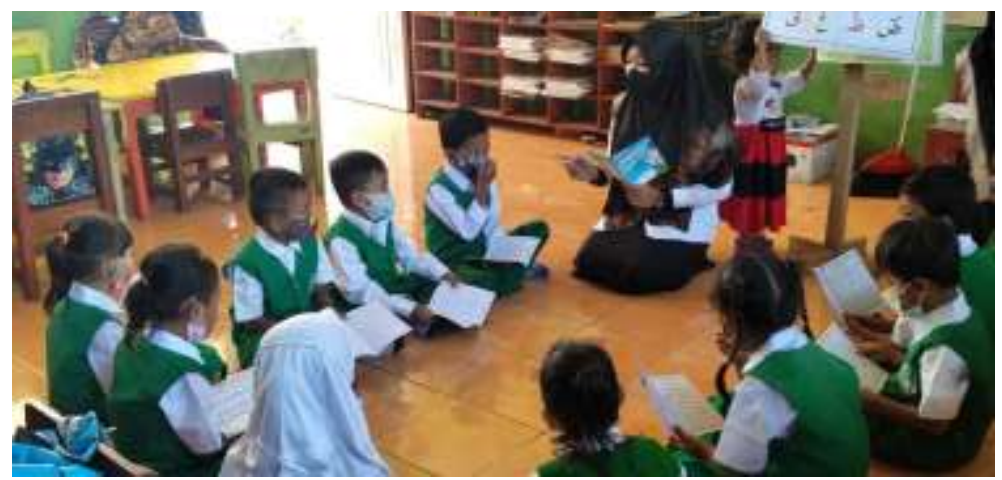

Figure 6. Closing Prayer

All those steps in implementing "Sekolah Sak Ngajine" Program and the time required for each meeting are shown on the table 1.

Table 1. Time Allocation for the 'Sekolah Sak Ngajine' Program

\begin{tabular}{cllll}
\hline Number & \multicolumn{1}{c}{ Step } & \multicolumn{1}{c}{ MATERIAL } & TECHNIQUE & \multicolumn{1}{c}{ TIME } \\
\hline $\mathbf{1}$ & First Step & Opening prayer & Classical & 5 minutes \\
$\mathbf{2}$ & Second Step & card display & Classical & 5 minutes \\
$\mathbf{3}$ & Third Step & Calendar viewer & Classical & 5 minutes \\
$\mathbf{4}$ & Fourth Step & Book & Individual & 20 minutes \\
$\mathbf{5}$ & Fifth Step & Calendar viewer & Classical & 5 minutes \\
$\mathbf{6}$ & Sixth Step & Closing pray & Classical & 5 minutes \\
Total Time Allocation Needed & & 45 minutes \\
\hline
\end{tabular}

\section{Munaqosyah Tilawati Based 'Sekolah Sak Ngajine' Program at RA Khodijah II}

If all stages of the implementation of the 'Sekolah Sak Ngajine' program have been carried out, then the final stage of implementing the 'Sekolah Sak Ngajine' program is Munaqosyah or also known as evaluation. Munaqosyah, or evaluation, is carried out to obtain data on the development of students after completing the process of learning the Koran using the tilawati method. In practice, students randomly read five pages (pages 34 to 44 ) using the Rost rhythm with a maximum duration of 5 minutes. The implementation of munaqosyah is carried out when students have reached the middle and end of the Tilawati PAUD volume. After completing Tilawati PAUD, students immediately continued Tilawati volumes 1-6.

So that the implementation of the 'Sekolah Sak Ngajine' Program can continue to run and continue to grow. The head of RA, together with the teacher council of RA Khodijah II, also makes an assessment or assessment schedule. The purpose of this assessment is so that the impact of the 'Sekolah Sak Ngajine' program can be felt by the school community in particular and the surrounding community in general. This assessment is implemented every semester to obtain information on what things need to be improved or improved and the extent of the positive impact obtained from the 'Sekolah Sak Ngajine' program. 
With the assessment of the 'Sekolah Sak Ngajine' program, it is known that the program can have a tremendous impact on students. The most significant impact is by instilling the habit of learning the Qur'an to students from an early age. It can foster a sense of love for the Qur'an from an early age in RA Khodijah II Sebaung, Gending District. This program can also be an attraction for the community around RA Khodijah II Sebaung, Gending District, to increase the number of students from 30 to 40 in the 2020-2021 school year.

\section{Discussion}

As one of the formal educational institutions with Islamic characteristics, an institution like RA should have the advantage of a clear religious commitment and excellent prospects. This is necessary to maintain the existence and quality of madrasah. Therefore, madrasah must innovate by setting the program at the highest level by the potential of the madrasah.

The 'Sekolah Sak Ngajine' program is an innovative tilawati-based Qur'an learning program implemented at RA Khodijah II. The Tilawati method is a teaching method for reading the Qur'an that uses the Rost tone of reading when reading the verses of the Qur'an (Santoso, 2018). Tilawati is one of several methods in the teaching and learning process of the Qur'an that has been introduced and proposed by its initiators from the level up to Kindergarten/RA, SD/MI, SMP/MTs, SMA/MA, and even universities. With this method, children are educated and guided so that they can read the Qur'an correctly, well, and fluently. In this method, from the beginner level (Tilawati PAUD and Volume I) to the advanced level (reading garib musykilat), students are introduced to one song while reciting the Qur'an.

The Tilawati method was developed in 2002 by a group consisting of Dr. H. Hasan Sadzila, Dr. H. Ali Muaffa, and his colleagues and later acquired by the virtual boarding school Nurul Falah in Surabaya (Khoiruddin, 2020). The Tilawati method was developed to overcome the problems faced by TK/TPA, among others: First, the quality of education for TK AlQur'an/TP graduates has not been adequate. Second, the teaching method has not created a conducive learning environment so the learning process becomes inefficient. Third, there is no financial balance between income and expenses. Fourth, learning time is still too long, so many students drop out of school before graduating from the Qur'an. Fifth, the TQA class after the TPA TPA cannot run optimally (Imtihanudin, 2020). The Tilawati method provides quality assurance for students, including students who can read the Qur'an with tartil: First, Students can forgive mistakes in reading the Koran. Second, completeness of training for individual students is $70 \%$, group $80 \%$.

Meanwhile, the principles of Tilawati's teachings are conveyed in a practical way using Rost songs and using a classical and individual approach in a sustainable manner (Ummah \& Wafi, 2017). In addition, the Tilawati method is taught in practice using Rost songs, taught classically using props, and taught individually using reading and listening techniques using books (Wahid et al., 2021). The media needed to teach reading the Qur'an tilawati include student textbooks and teaching equipment such as display cards and calendars (Hambali et al., 2021). This method is combined with the sitting position used, which is semi-circle or Ushaped, which aims to maintain a supportive learning atmosphere with the teacher in front of the center, thus facilitating interaction between teachers and students (Zamroni et al., 2021).

The 'Sekolah Sak Ngajine' program also focuses on the habit of loving the Quran from an early age. Habituation is a behavior that is achieved through lifelong learning and eventually becomes consistent and spontaneous. This method can make it easier to teach, guide, and tame students to consistently achieve their goals, so they take root in the child and become a habit that is difficult to break (Saugi, 2020; Rozi et al., 2021; Wahyudin et al., 2021; Purnomo et al., 2021). Because if habituation is carried out with a structured and organized system, learning outcomes will be obtained in the form of optimal character formation (Wiyani \& Purwokerto, 2020; Dakir et al., 2021). In this case, the character to be achieved is the love of the Quran. 
This is in line with the fact that the most critical education to be instilled from childhood is the love of the Qur'an. Because by loving the Qur'an, children will love God and His Messenger, as well as their family and religion (Ahsanulkhaq, 2019). This love for the Qur'an must be instilled in children before teaching them to memorize the verses of the Qur'an (Minan \& Suhendro, 2020). This is because memorizing the Qur'an without loving the holy book will not produce anything. Scholars and Salafists have also defended the importance of studying the Qur'an since childhood, including:

Imam Al-Ghazali, in his book Ihya Ulum Al-Din, mentions the importance of teaching children the Qur'an, Hadith of the Prophet, pious stories, and some basic religious laws (Rahmawati, 2019). Meanwhile, Ibn Khaldun in Al-Mukaddimah mentions the importance of studying the Qur'an since childhood as a spiritual father to strengthen his faith and piety (Masykur, 2021). Regarding Ibn Sin, in his book As-Siyasah, he emphasizes the importance of studying the Qur'an from an early age to improve the quality of the original Arabic language and instill in it the signs of faith (Purba \& Maturidi, 2019).

\section{CONCLUSION}

This research focuses on applying the 'Sekolah Sak Ngajine' program in RA Khodijah II. This program was created to habituate to love the Quran from an early age through tilawati learning. The research found that the classical and individual Qur'an learning methods can condition the tendency of children to be active so the targets can be achieved well. In addition, teaching media such as card displays, calendars, and books can attract the attention of students, especially with Rost songs used to read the Qur'an. This study implies that learning the Qur'an for early childhood requires creativity and patience of teachers.

\section{ACKNOWLEDGMENT}

The researcher would like to thank the Chancellor of the State Islamic University Kiai Haji Achmad Siddiq Jember and the Chancellor of the University of Nurul Jadid, Paiton, Probolinggo, East Java, and all residents of RA Khodijah II Sebaung, Gending District, Probolinggo Regency, who have provided motivation and support for the completion of this research. Hopefully, this research will provide benefits and inspiration for further researchers in developing learning innovations in schools.

\section{REFERENCES}

Ahsanulkhaq, M. (2019). Membentuk Karakter Religius Peserta Didik Melalui Metode Pembiasaan. Jurnal Prakarsa Paedagogia, 2(1).

Akbar, E. (2017). A2MIPARI (Aksi Anak Membaca Iqra' Pagi Hari) Pembelajaran Al Quran Pada Pendidikan Anak Usia Dini "Ash-Shiby." Jurnal Al Athfal, 3(2), 197-208. https://doi.org/10.14421/al-athfal.2017.32-07

Ali, M. A., \& Hussien, S. (2017). Iqbal's Inferences from the Qur'an: Objectives of Education for Developing the Individual Self. Journal of Education and Educational Development, 4(2), 321. https:// doi.org/10.22555/joeed.v4i2.1357

Ali, M. A., \& Hussien, S. (2018). Iqbal ' s Inferences from the Qur ' an : Educational Objectives for Developing an Individual for Serving Millat. Journal of Education and Educational Development, 5(1), 139-155. https://doi.org/10.22555/joeed.v5i1.1924

Ali, R., \& Harahap, R. H. (2021). Evaluation of Education and Training Program At Medan Religious Training Center. Al-Tanzim: Jurnal Manajemen Pendidikan Islam, 5(2), 75-85.

Amin, M., \& Ramli, M. (2019). Implementasi Metode Tilawati Dalam Pembelajaran Al Qur'an Pada Anak-Anak Di Tpa Al Falah Unit 081 Kota Banjarbaru. Al Falah, Vol. 19 No, 161-178.

Dakir, Wibowo, A., Zamroni, Rozi, F., Misroto, Muqoddam, A., \& Bon, A. T. (2021). Efforts to Improve Student Learning Outcomes; Identification of Learning Models in Madrasah. IEOM Society International.

Eka, P. (2017). Konsep Pendidikan Anak Menurut Al-Qur'an Perspektif Muhammad Quraish Shihab. TADBIR :Jurnal Manajemen Pendidikan Islam, 5(1), 116-131. 
Hambali, H., Rozi, F., \& Farida, N. (2021). Pengelolaan Pembelajaran Ilmu Tajwid Melalui Media Audio Visual. NATURALISTIC: Jurnal Kajian Penelitian Pendidikan Dan Pembelajaran, 5(2), 872-881. https://doi.org/10.35568/naturalistic.v5i2.1180

Hidayati, E. W. (2018). Mencetak Generasi Anak Usia Dini yang Berjiwa Qur'ani dalam Perspektif Pendidikan Agama Islam. Journal of Childhood Education, 2(2), 147-175. https://doi.org/10.30736/jce.v1i2.12

Imtihanudin, D. (2020). Model Penanaman Karakter Dalam Pembelajaran Al Qur'an Metode Tilawati. Cakrawala Pedagogik, 4(1), 106-112. https://doi.org/10.51499/cp.v4i1.146 https://doi.org/10.51499/cp.v4i1.146

Jannah, A. N. (2021). Wawancara Guru RA Khodijah II.

Julianto, T. A. (2020). Metode Menghafal dan Memahami al-Qur'an bagi anak usia dini melalui Gerakan Isyarat ACQ. IQRO: Journal of Islamic Education, 3(1), 71-84.

Khoiruddin, H. (2020). Manajemen Pembelajaran Tahsin Al Quran Berbasis Metode Tilawati. Jurnal Isema, 5(1), 55-68. https://doi.org/10.15575/isema.v5i1.5546

Mansur, R. (2017). Lingkungan yang Mendidik Sebagai Wahana Pembentukan Karakter Anak. Jurnal Pendidikan Agama Islam, 2(2), 33-46.

Masykur, F. (2021). Konsepsi Keilmuan Dan Pendidikan Islam Menurut Ibnu Khaldun. TaRBAWI : Jurnal Pemikiran Dan Pendidikan Islam, 4(1), 1-19.

Maulidiyah, H. (2021). Wawancara Guru RA Khodijah II.

Minan, M. A., \& Suhendro, E. (2020). Pembelajaran Tahfizh Al-Qur'an Dan Implikasinya Terhadap Pendidikan Karakter Di Pondok Yanbu'Ul Qur'an Anak-Anak Kudus. Jurnal AT TAHFIZH, 2(1), 60-80.

Mulyani, D., Pamungkas, I., \& Inten, D. N. (2018). Al-Quran Literacy for Early Childhood with Storytelling Techniques. Jurnal Obsesi : Jurnal Pendidikan Anak Usia Dini, 2(2), 202. https://doi.org/10.31004/obsesi.v2i2.72

Purba, A., \& Maturidi. (2019). Mendidik Anak dalam Mencintai Al- Qur' an Mendidik Anak dalam Mencintai Al- Qur' an. Edukasi Islami: Jurnal Pendidikan Islam, 8(2), 347-368.

Purnomo, H., Chaer, M. T., \& Mansir, F. (2021). Humanistic Public Service Education in Government Gamping Sub-District Yogyakarta. Al-Tanzim: Jurnal Manajemen Pendidikan Islam, 5(2), 52-61.

Pusvitasari, R. (2021). Human Resource Management in Improving The Quality of Education. AlTanzim: Jurnal Manajemen Pendidikan Islam, 5(2), 125-135. https://doi.org/10.51276/edu.v2i2.132

Rahmawati, M. (2019). Mendidik Anak Usia Dini dengan Berlandaskan Pemikiran Tokoh Islam AlGhazali. Al Fitrah: Journal of Early Childhood Islamic Education, 2(1), 229-241. https://doi.org/10.29300/alfitrah.v2i2.2271

Robi, Sugiatno, Muhammad Taqqiyudin, Amimah Qodari, A. (2020). Kerjasama orangtua dan guru pai dalam memotivasi siswa menghafal al qur'an. Al-Ikhtibar: Jurnal Ilmu Pendidikan, 7(2), 774-786. https://doi.org/10.32505/ikhtibar.v7i2.615

Rosada, R., \& Sasmanda, S. (2018). Pembiasaan Cinta Al-Qur'an Dan Hadist Pada Anak Usia Dini Untuk Membentuk Karakter Islami Siswa Pada Paud Nur Al-Banna Gerung. Paedagoria | FKIP UMMat, 6(1), 70. https:// doi.org/10.31764/paedagoria.v6i1.144

Rozi, F., Rosidah, R., Ni'mah, M., Masun, H., Juaeriyah, K., \& Maimuna. (2021). Blended Learning Approach in Arabic Learning. Journal of Physics: Conference Series, 1779(1). https:// doi.org/10.1088/1742-6596/1779/1/012065

Santosa, Rochmat Budi; Nurkamto, Joko; Baidan, N. S. (2016). Pragmatic Study of Directive Speech Acts in Stories in Alquran. Advances in Language and Literary Studies, 7(5). https://doi.org/10.7575/aiac.alls.v.7n.5p.78

Santoso, S. A. (2018). Implementasi Metode Iqra' Dan Metode Tilawati Dalam Pembelajaran. Annaba: Jurnal Pendidikan Islam, 4(1). https://doi.org/10.37286/ojs.v4i1.32

Saugi, D. M. \& W. (2020). Implementasi Metode Pembiasaan Guna Meningkatkan Pencapaian Mahasiswa KKI 3 dalam Menghafal Al-Qur'an di IAIN Samarinda | Maria | Jurnal Tarbiyah dan Ilmu Keguruan Borneo. Jurnal Tarbiyah \& Ilmu Keguruan (JTIK) Borneo, 1(1), 203-213. https://doi.org/10.24239/albariq.v1i2.6 
Syaikhon, M. (2017). Penerapan Metode Tilawati Dalam Pembelajaran Membaca Alqur'an Pada Anak Usia Dini Di Kb Taam Adinda Menganti Gresik. Education and Human Development Journal, 2(1). https://doi.org/10.33086/ehdj.v2i1.394

Taja, N., Inten, D. N., \& Hakim, A. (2019). Upaya Meningkatkan Keterampilan Mengajar Baca Tulis Al-Qur'an bagi Guru. Jurnal Obsesi: Jurnal Pendidikan Anak Usia Dini, 3(1), 68. https://doi.org/10.31004/obsesi.v3i1.135

Trihapsari, C., \& Mujahidah, F. (2021). Enhancement of the Quality of Human Resources Through Training and Development Programs in Schools. Al-Tanzim: Jurnal Manajemen Pendidikan Islam, 5(2), 145-153. Retrieved from https://ejournal.unuja.ac.id/index.php/al-tanzim/article/view/2325

Ummah, S. S., \& Wafi, A. (2017). Metode-Metode Praktis dan Efektif dalam Mengajar Al-Quran bagi Anak Usia Dini. Proceedings of The 2nd Annual Conference on Islamic Early Childhood Education, 2, 121-134.

Ustidz. (2021). Wawancara Kepala RA Khodijah II.

Wahid, A. H., Rozi, F., Baharun, H., Hidayati, W., \& Bon, A. T. (2021). Information Technology in the Development of Language Aspects of Early Childhood.

Wahyudin, U. R., Winara, D., \& Permana, H. (2021). Teacher Professionalism Improvement Management: Study of Principal Leadership at Sma Al-Ittihad Karang Tengah Cianjur. AlTanzim: Jurnal Manajemen Pendidikan Islam, 5(2), 115-124.

Wiyani, N. A., \& Purwokerto, I. (2020). Manajemen Program Pembiasaan Untuk Membentuk Karakter Mandiri Pada Anak di Paud Banyu Belik Purwokerto. Jurnal Thufula, 8(1). https://doi.org/10.21043/thufula.v8i1.7044

Zamroni, Amir, \& Saleha, L. (2021). Pengelolaan APE Berbahan Limbah untuk Meningkatkan Kecerdasan Kognitif Anak. Jurnal Obsesi: Jurnal Pendidikan Anak Usia Dini, 5(2), 13821395. https://doi.org/10.31004/obsesi.v5i2.763 